\title{
Unknown Strong Earthquakes of The North- Western Caucasus in Holocene and Long-Term Seismic Regime
}

ISSN: 2578-0255

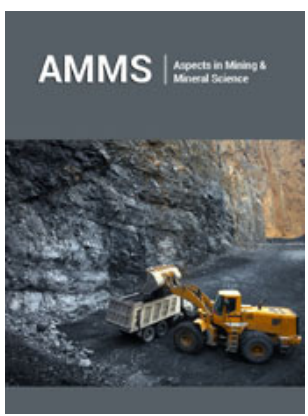

*Corresponding author: Evgenii Rogozhin, Shmidt Institute of Physics of the Earth, Russian Academy of Science, Russia

Submission: 海 August 22, 2019

Published: 海 September 16, 2019

Volume 3 - Issue 3

How to cite this article: Evgenii Rogozhin. Unknown Strong Earthquakes of The North-Western Caucasus in Holocene and Long-Term Seismic Regime. Aspects Min Miner Sci.3(3). AMMS.000570.2019.

DOI: 10.31031/AMMS.2019.03.000570

Copyright@ Evgenii Rogozhin, This article is distributed under the terms of the Creative Commons Attribution 4.0 International License, which permits unrestricted use and redistribution provided that the original author and source are credited.

\section{Evgenii Rogozhin*}

Shmidt Institute of Physics of the Earth, Russian Academy of Science, Russia

\section{Opinion}

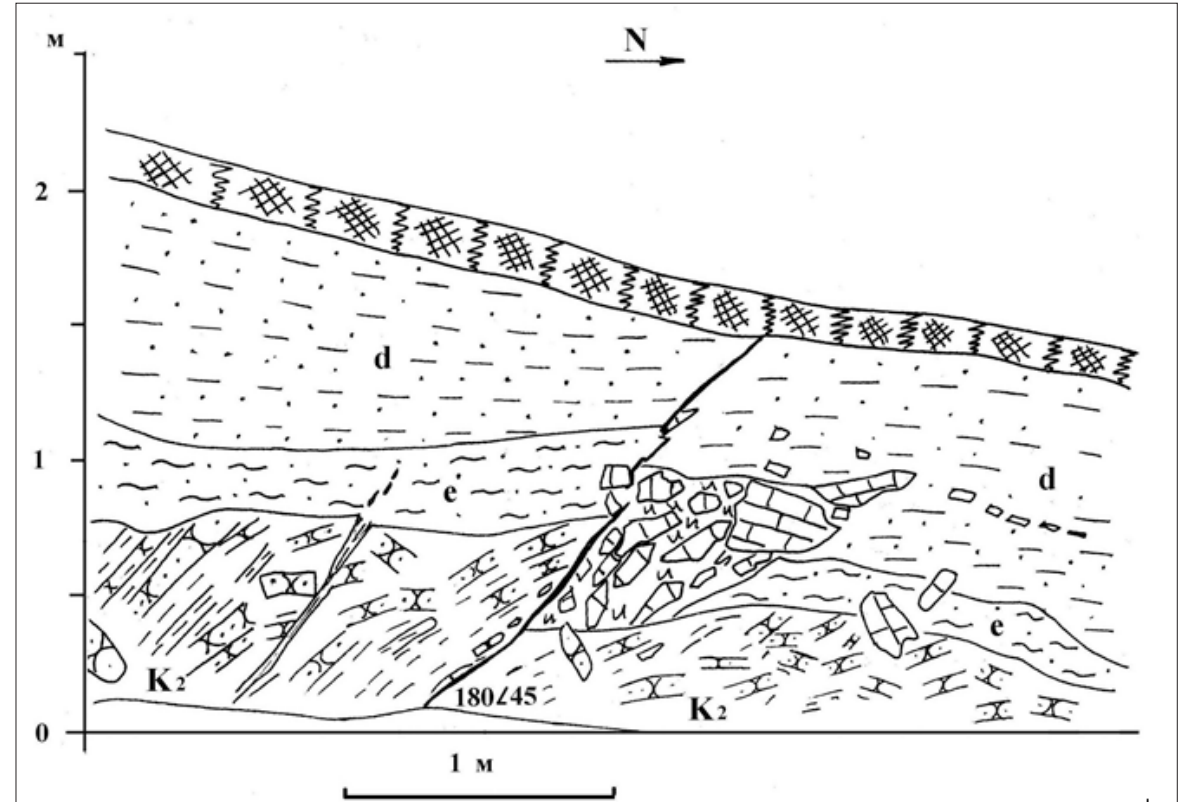

Figure 1: Ancient displacement in the area of Kuznetsovsky fault (detailed sketches of the trench wall). In the central part of section, the colluvium wage is presented.

Studies and mapping on terrain seismogenic areas and determination of their modern seismic potential for the territory of the North-Western (Russian) Caucasus was fulfilled. With the especial detailed where explored areas of largest neotectonic faults in the region. On the south limb of the North-Western Caucasus near the important tectonic boundary between the Caucasus folded belt and the Transcaucasian microplate the primary and secondary seismic ruptures of unknown ancient and known historical strong earthquakes (seismic faults, landslides, fissures) were discovered. Using an informative method of trenching enable to estimate a recurrence interval of seismic shocks in a few seismic faults. This study in trenches to manage to define an absolute age of the seismic offsets, having place in Holocene on Kuznetsovsky (Figure 1), Verkhnekhazar and Costal fault zones. Violated paleosoils have absolute age $990 \pm 100$ years (IGAN 2126) for first fault and $520 \pm 80$ years (IGAN 2118) for the second one. These seismic motions manage to identify with known but referred to other seismic zone by strong earthquakes Crimean-Kuban' region, occurred on $1341 \pm 1$ and 16 Septembers 1799. The seismic events magnitude was about 7.0, intensity-from 8 to 9. Determination of paleosoils and bones from the area of the Coastal fault absolute age, denominated on surfaces in the manner of systems of escarps, small graben and gravitationalseismotectonic ruptures, has allowed to estimate periods of stability of the structure of $130 \pm 40$, $6840 \pm 230,5210 \pm 200,8600 \pm 190$ years (IGAN-2417, 2418, 2429, 2427) and 2980 \pm 90 years (GIN-11728) ago. This signifies, that periods of activations of the structure, when colluvial and deluvial Late Quaternary deposits accumulated, are correspondent at the time of near3000, 
5000, 6600, 8400 and, probably, 10200 years ago. Magnitude of the paleo earthquakes generating ancient ruptures were estimated from the amplitude of co-seismic offsets in the Kuznetsovsky and Verkhnekhazar active faults of 7.0-7.5. Thereby, the recurrence interval of strong earthquakes in the studied region is measured in 2 thousand years approximately. Seismological (historical and instrumental) data concerning earthquakes with $\mathrm{M}=4-6.5$ became the base of magnitude-frequency relation with slope $b=-$ 0.97 and coefficient correlation $\mathrm{R}=0.973$. Joint relation, compiled both seismological and paleo-seismological data, has $b=-0.94$ and $\mathrm{R}=0.986$ (Figure 2). This decreasing of $\mathrm{b}$ brings to some increasing of strong earthquake frequency compared to one obtained after preceding plot extrapolation into large magnitude area. Local variations of the modern soil thickness in zone of three active faults, studied in trenches demonstrated the vertical creep movements along the fault planes during last 100 years with average velocities 1.5-2.0mm per year.

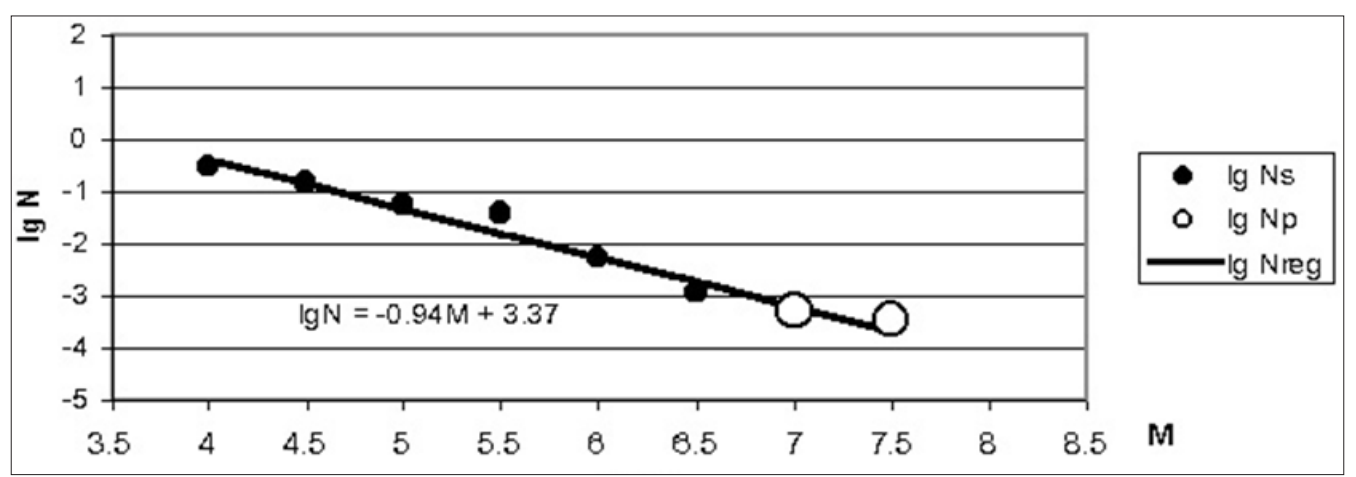

Figure 2: A recurrence plot of the frequency of occurrence of earthquakes in the region of North-Western Caucasus. Ns is the number of earthquakes of a certain magnitude per year according to instrumental and historical data, $\mathrm{Np}$ is the same according to paleo seismological data, Nreg is the line of the graph.

\section{Funding}

The study was supported by the Russian Foundation for Basic Research (project nos. 18-05-00641_a, 19-55- 53017 GFEN_a). 